\title{
Back to Java: The discourse of Lombok art in Salman Faris's Kenari Mentaram
}

\author{
Dharma Satrya HD, Baiq Rismarini Nursaly* \\ Departement of Language, Arts, and Humanities \\ Universitas Hamzanwadi, Indonesia \\ *Correponding Author \\ Email: rismarini09@gmail.com
}

Received:

Revised:

Accepted:

Published:

28 October 2019

9 February 2021

14 February 2021

28 February 2021

\begin{abstract}
This article is triggered by the emergence of ethnicity aspects in Indonesian literature. The importance of ethnicity in Indonesian literature is because Indonesian literature is assumed to be plural, not singular. That is, the reality of Indonesia in Indonesian literature is not limited to one ethnicity, but various ethnicities. In the perspective of modern Indonesian literature, Indonesian novels are synonymous with Malay, Jakarta, Java and several other cities that have contributed to the development of Indonesian literature. In the perspective of ethnic Indonesian literature, Indonesian novels are identical with ethnicities whose existence is ignored in modern Indonesian literature. In this context, ethnic Indonesian literature is important to explore. This article explores the interesting representation of Lombok in Ethnic Indonesian literature. Lombok serves an ethnic that needs to be analyzed in Indonesian literature, because Lombok is assumed to be part of Java (Marrison, 1999; Meij 2011) and Lombok is hegemonyed in Java (Satrya, 2018). The problem is whether Indonesian literature still represents Lombok as shown by Marrison, Meij, and Satrya in the study of philology and literature. The Indonesian novel of Lombok delineating the issue of Java in interpreting Lombok is the novel Kenari Mentaram (2013) by Salman Faris. This article applies Stuart Hall's representation theory and model. Based on that theory, the novel Kenari Mentaram is assumed to be a production of meaning regarding Lombok. The analytical method uses the semiotic analysis method and the Stuart Hall discourse model. Lombok is interpreted in the novel Kenari Mentaram in the context of internationalization. In this context, Lombok's art is the only commodity that can be sold. The art of Lombok represented is the art of Lombok which is capable of competing internationally by taking a model from Java. Thus, the internationalization of Lombok can only be done by taking the Javanese Model. In the internationalization context, the discourse of Lombok art discussed is the multicultural art of Lombok. The Kenari Mentaram novel delineates as part of the discourse of the nationalization of Lombok in the context of Indonesian literature and the internationalization of Lombok in the context of tourism.
\end{abstract}

Keywords: ethnic Indonesian literature; Lombok; novels; nationalization; internationalization; tourism 


\section{INTRODUCTION}

A discourse in Indonesian literature as explained by Faruk (1995, pp. 2-3) is attracted to two reverse directions. The first direction flows to the past and the second direction flows to the future. The first is called as centripetal nationalism while the second one is called as centrifugal nationalism. The second type of nationalism is more dominant (Faruk, 1995, p. 3). New decade of poet represents that kind of nationalism.

Nationalism in modern indonesian literature is a nationalism which celebrates human as a free individual. Nationalism in indonesian literature which then moves into the past, bring back the myth. In that phase, human is not totally free. Nevertheless, there are strengths outside the human, which is magical. In that kind of nationalism, the presence of the past is presented into the recent day. That nationalism collides with what is called by Faruk (2018, p. 384) as a poetic nationalism, "easy bored nationalism", which refuses the repetition.

That kind of nationalism which appears in contemporary Indonesian literature with the ethnical cases, the nationalism which produces consumerism culture. That kind of nationalism produces novel Kenari Mentaram. That novel is assigned as the resurrection of a revived phase of Lombok in Indonesian literature. In its resurrection context, that novel describes Lombok as a satisfaction object. That package is served to be enjoyed internationally. The articulation of Lombok in the context of Indonesian literature is the effort of nationalization and internationalization of Lombok. That kind of effort is also conducted by Satrya (2018; 2019) who compares the novel Ketika Cinta Tak Mau Pergi with the novel Opto Ergo Sum. In that context, the literature discourse and academic discourse can support each other. The ethnics, which are rarely represented in the literature (Indonesia) in the context of nationalism, revive to sound its identity (Kurnia, 2015; Sesnic, 2007; Subardini, 2011; Suroso, 2011; Wildan, 2013).

\section{The construction of park in novel Kenari Mentaram}

The option of tourism setting in the novel is the locations located in tourism area of Mataram City. Some locations described are Loang Balok Park, Sangkareang Park, and Udayana Park.

At 4.30 in the afternoon. As what is planned, Cheng gathered with his friends at Loang Balok Park. They meet very often there, joking each other, and even camping there. They never feel bored. The more often they enjoy the park, the more they found many new things. There should be something that they want to find. Then, that finding bounds their holy bond tighter, as if it is similar with the white writing in the edge of the park (Faris, 2013, p. 12).

Loang Balok Park is connected to some activities such as playing, camping, the places to found many things, and the place to bound togetherness. Loang Balok Park is constructed as an enjoyable place for teenagers to play. Yet, the problem is why should Loang Balok Park, not Loang Balok Tomb which is discussed in the novel. The tomb has strong relation with spiritual things, meanwhile park has correlation with playing, because park is a place which can be visited by people in their leisure time. This side of the park is more important to be showed rather than from the side of the tomb. The characters 
of Cheng and his friends are narrated as the student of senior high school, then park becomes a place to play and gather with friends. Loang Balok Tomb is identical with the ritual of Saur Sesangi. Besides Loang Balok Park, Sangkareang Park is also presented as the gathering place of teenagers.

The situation of Saturday night at Sangkareang Park becoming more live. Not only people who sell various kinds of food and beverage, there are many teenagers who are in love gather just like the birds which fly together under the clear sky of Mataram City. Instead, many parents also bring their children to enjoy the night there, to leave the television in their home for a while (Faris, 2013, p. 63).

Sangkareang Park is constructed as a place to spend the Saturday night with close friend and the place for family to seek entertainmet or just to enjoy the night. In the park, there are many kinds of food and beverage stalls provided there. The place is constructed as the centre of Mataram City and the places to held big events in Mataram such as music parade, music concert, exhibition, and others. The online media and the novel construct Sangkareang Park and Loang Balok Park as strategic tourism location in Mataram. The both locations are not the centre of the most visited location. This novel makes Udayana Park as the centre of tourism in Mataram. Udayana Park is made as the location of art event designed and conducted by five mataram people.

All participants are getting closer. The visitors, too. Udayana Road becomes a sea of people and an ocean of the attraction from creative groups that is initiated by Lima Kenari Mentaram.

Klimkas!

Husen shouted to give a signal through the megaphone that had begun to decrease the battery energy, so he pushed his voice out. All coordinators catch the signal, then conveyed to their group members. The ending of attraction starts soon. All participants supposed to be trained to attract at the peak of the show together. Quickly, including the Barongsai, which became increasingly attractive, controlled the entire road. In a matter of minutes, all participants formed the words "Bani and Tao". Then followed by the words "Kanak Mentaram Bani", and writing "Kanak Mentaram Tao" (Faris, 2013, p. 90).

The citation shows that Udayana Park is made as the location of the art event which can attract attention of many visitors, so that Udayana Park is crowded by people, becoming the sea of human and attractive ocean.

\section{Udayana Park as the art space}

Lima anak Mataram makes Udayana Park as a space to explore arts. The art event proposed by that creative group was conducted in there.

A week before the event, Subar had met with Haji Ramiun to request permission to use the road in Udayana Park where the event is planned to be held (Faris, 2013, p. 81).

Hadroh!

Husen gives a loud signal and immediatley Hadroh stomped. Subar fulfilled its promise. He collected more than five hundred hadroh tools. He went to all Islamic boarding schools in Mataram to borrow hadroh instruments. In fact, he went to Jerneng, a boarding school led by Tuan Guru Ulul near Perampuan Village. The association of pesantren students was immediately moved. They scramble to get involved. They train themselves. Subar only gave a hint of a few 
Satrya HD, D., \& Nursaly, B.R. (2021). Back to Java: The discourse of Lombok art in Salman Faris's Kenari Mentaram. EduLite: Journal of English Education, Literature, and Culture, 6 (1), 179-188. http://dx.doi.org/10.30659/e.6.1.179-188

songs that had to be trained. After that, later meet in the field during the attraction. On behalf of Bismillah, all participants had a demonstration of skill. Proven. Hadroh's voice immediately blared. The people on the Udayana road bridge were shocked. They are looking for sound sources of musical instruments that are familiar in their ears (Faris, 2013, pp. 84-85).

Sholawat!

Husen gave the command once more. At that time, he used a megaphone so his voice would not drown in the roar of the hadroh. Sholawat participants who were not less than seven hundred people immediately took action. Of course, the people in the Haji Ramiun village immediately shuddered. Throughout their ages, this was the first time they had heard the sweet prayer that was echoed melodiously. For those who have made the pilgrimage immediately thought as if they were in the Masjidil Haram. As if that's what happened (Faris, 2013, p. 85).

Rimpu!

On Husen's signal whose face had been soaked in sweat. He ran here and there to see the situation. While Atun who served as a documentary took a dual role. As soon as Husen gave a signal to the mobile group, he immediately ran to the gathering place of the group. And immediately, more than eight hundred groups of Rimpu moved slowly. Their faces and bodies are covered with Bima-colored fabrics. No wonder, a sea of beauty will soon be created (Faris, 2013, p. 87). Singing!

Husen's signal was immediately implemented by Atun. At that moment, the group, all of which were already on the Udayana road, sang the song "Syukur" which was translated into Bimanese, followed by Sasaknes, and Samawa language. Surprisingly, the song was composed in Chinese and Balinese. Like spreading magical power. Sky power. The entire community on Udayana Street immediately shuddered. Solid match for hadroh, sholawat and the song "Syukur" made them silent. For all that, without being led by anyone, not even one police officer, they stood neatly on the sidewalk of Udayana. They witnessed attractions that they had never expected at all (Faris, 2013, pp. 87-88).

Three minutes ago, Nengah gave the instruction.

Then began the dance "Millennium Mentaram." About six hundred dancers under Nengah's responsibility moved slowly. Their entire bodies were painted metallic. Their movements were like robots while imitating the sound of robots coming from nowhere. The dance group "Millennium Mentaram" continued to move to the south (Faris, 2013, p. 89).

Various arts from different ethnics were showed in Udayana Park. Lima anak Mataram who comes from different ethnics displayed various kinds of art from different traditions such as pesantren, Bima, and Bali. The art presented was Hadroh from pesantren tradition, Barongsai from China, Rimpu from Bima, Milenium dance, and songs from various languages. Those kinds of art were showed at Udayana Park. The art show arranged by Lima anak Mataram was attended by the Mayor of Mataram City, Haji Mohan Roliskana.

\section{Art and tourism: The policy of the mayor of Mataram city}

The government of Mataram City conducts a meeting to discuss the art show that they saw at Udayana Park.

The meeting scheduled at 9am in the morning was titled, "Policy is a must", so that all assistants, SKPD heads, and other officials were present twenty minutes before the meeting began. A scene that may rarely occurred. All meeting participants brought the Lombok Post newspaper, Suara NTB newspaper, and other local newspapers in NTB (Faris, 2013, p. 95). 
This is not just talking about tourism, it also involves culture. In fact, if we succeed in taking this momentum, it means that we have built a strong and deeply rooted tradition in the formation of the civilization of Mataram City. For this reason, I emphasize to the tourism office, mobilize all available resources. I do not want to hear a simple target. Yesterday's events taught me one belief, we can make cultural events that are far greater than any country (Faris, 2013, p. 100).

We encourage indigenous events, forms and cultural values in Mataram City to be more progressive, so that they can keep up with the times. In other words, the people of Mataram City not only inherit cultural values, but also obtain other benefits. For example, culinary traditions and the production of lontong, pesor, which have been going on for hundreds of years in Punie, we pack them into cultural performances. And in the event that is being initiated, this tradition will become not only a cultural event, but an industrial (Faris, 2013, p. 103).

The government of Mataram City conducted a meeting with all heads of department to formulate or plan the art show. The government of Mataram City made Lima anak Mataram as the organizer of the art show. The government of Mataram City and including Lima anak Mataram dream about a globalized Mataram City through the art show.

\section{Internationalization of Lombok through arts}

Art is used as the means to achieve the goal that is the internationalization of Mataram City.

Lima Kenari Mentaram automatically nod their heads. Their hands continued to move down the sentences of Haji Jalal even though they rarely saw the notes because their eyes were centered on Haji Jalal. The word Mataram translates to Sanskrit, matta means mother country and ramya means crowded, good, or beautiful. Matta can also be interpreted as the eye, paningal, blind. Thus, as a native of Mataram, you must have an awareness of the courage to sacrifice, fight, and risk all honor to offer a glorious achievement to Mataram as the mother of the soul of all Mataram people. The aim is that Mataram has dignity in international and national eyes. Mataram must be made into a city that is visited by people from all parts of the world. Although Mataram is built based on the principles of beauty to look beautiful, orderly, neat, clean, safe, and green. That way, everyone who visits Mataram feels they want to stay longer (Faris, 2013, p. 122).

Haji Jalal constructs the meaning of Mataram City as a peaceful, crowded and beatiful place. Lima Anak Mataram is asked to realize Mataram becoming a crowded and beautiful city. The effort to realize Mataram becoming the most visited place by the people from all around the world is an effort to make Mataram becoming a tourism city. To invite many visitors, Mataram is built by the principles of beauty. The concept of beauty emphasized is the beauty in realizing a neat, safe, and green city. That beauty is discoursed to attract the attention of tourists to stay longer. Lima anak Mataram successfully brings Mataram into the world. They present an interesting art show to the world.

The highlight of the event, on the main stage there, all members of Lima Kenari Mentaram dressed in school clothes each in white and gray, sitting flanked by the head of the APEC state and other world leaders. Meanwhile, all film crews directed by Ang Lee with high talent brought their own roles, so that they did not interfere in the slightest of the super international event. Far out there, local 
directors were only silent and licked their saliva because they felt cheated by their limited imagination and reason in capturing the secrets of the land of Mentaram (Faris, 2013, p. 218).

The art show presented by Lima anak Mataram can invite the leaders of APEC countries and other world figures. The citation above shows that Lima anak mataram are the students who still study in senior high school becasue they wear the uniform. The government of Mataram City entrust the biggest event of the city to high school students. This novel constructs the creative teenagers in building Mataram City. Lima anak mataram who are involved in that big event are Lima anak Mataram from different ethnics. Their difference is the essential thing in preparing that big event.

\section{The discourse of Lombok art in novel Kenari Mentaram}

The difference of the ethnics from Lima anak Mataram is made as the main thing in presenting the art show at Mataram City.

We come from different places, why don't we combine it as a masterpiece?

I still don't follow you.

Husen emphasizes his confusion.

I have Barongsai. I also have keroncong music group.

Emmmm. Then?

Husen is starting to get the point of conversation. What do you have?

Cheng asks Subar.

I have kasidah. All friends of mine at Pondok Pesantren Darul Falah can perform sholawat and their voices are amazing. We also have many kasidah equipment.

Great. That's what I mean. And you, Nengah?

I can dance. I have dance studio with more than fifty members. Besides learn about Balinese dance and classic sasak dance, I also learn about modern dance by inviting teachers from ISI Denpasar who are coincidently the friends of my uncle (Faris, 2013, p. 71).

Lima anak Mataram comes from the different ethnics. Cheng, Atun, Husen, Subar, Nengah and each of them shows the ethnics of China, Bima, Arab, Sasak, and Bali. Lima anak Mataram wants to combine their difference becoming a clever show. Cheng offers Barongsai which is the icon of China's culture. Subar has kasidah. Nengah is ready to present Balinese dance. Sasak ethnic represented by Subar is a moslem sasak, Sasak pesantren. Nengah, as a representation from Balinese in Mataram, masters not only Balinese dance, but also classic sasak dance and modern dance. The combination from those different ethnics is assumed as multicultural arts. Multicultural is an art discourse at Mataram City. This discourse is proposed by Trisnawati (2016) in the context of tourism.

\section{Java as the model}

Java is considered as the model for Lima anak Mataram. Java which is made as the model is Jember. Cheng brings story from Java.

Cheng began the story, accompanied by the song from Rhoma Irama, faintly heard from the Sekarbela mosque who were accompanying people there who were still working together. This is how he begins his story:

The afternoon sun feels different. Very hot. Blazing that I've never felt. As hot as Mataram is, it's never felt until you want to burn your body's contents. But the 
heat at that time was really different. The sun's heat is increasingly burning because I have to crowded together, fighting over the right place and right with hundreds of thousands of spectators. Everyone present has the same intention and purpose. Take part in the tumult of the big party which is held once a year. The main road in Jember City along approximately 3.6 kilometers was completely full. Even, Ants feel like they don't have a place. Solid docked. All spectators crammed alongside the road alongside the participants who would show their creations. Beginning, the participants comprising 600 people gathered at the town square in Jember. Like a sea of beauty in various shapes and colors. Everyone displays a different style. Some of them have just joined, some have been involved in the event since they were first held. The beauty of all the participants was being siblings. Because they did not come to the event to show their strength, arrogance, and malice. They come there to share knowledge and skills. Sharing cheerfulness, fun and happiness. The audience is no less exciting. All ages are overflowing. None of their faces were troubled. All release the burden. God was truly happy that day in the city of Jember

(Faris, 2013, pp. 46-47).

I also briefly watched the faces of several participants. Implied in their eyes, as if to say that the world must be freed from war. Every human being must be freed from heinous politics. As if they wanted to shout. Even though the country is wiped out by corruptors, let them party in hell, but in the city of Jember, happiness is sown for every soul. The radiant of their faces seemed to confirm that everyone was free to become a useful human being, free from the bondage of social suffering (Faris, 2013, p. 47).

In Java, Cheng saw Jember festival. Then, he retold what he saw there to his friends. Cheng highlights the condition of Jember City and its crowded caused by that festival. The hot weather in that city does not disturb the visitors. Cheng describes that with that crowd, event an ant does not have space. Besides, Cheng also concern to the differences in that festival. All visitor who come and all shows presented there according to Cheng are knowledge, skill, pleasure, and peace. The discourse of variety in this novel is also constructed by Budiwanti (2014) in describing the ritual of Puja Wali and Perang Topat in Lombok.

The story from Java told by Cheng was made as the model by Liima anak Mataram in presenting the cultural event in Mataram City.

It doesn't matter if we show that we imitate the events that have been recognized for their greatness in the world, such as Jember Fashion Carnaval, Rio de Janeiro Carnaval, but we also show that we are different. There is something new in the impersonation. For me, imitating is very different from following. Imitators are very different from plagiarists. If the imitator makes the object which is imitated as the source of the creation of new works, while the plagiarist just do a copy paste. For example, we may imitate the idols made by television, but do not let our character as a native of Mataram disappears. The idol is only as an inspiration, the rest, we determine what we want to be. We have to create trends, even though before we saw smart trends from other people. Do not children can only be followers of trends (Faris, 2013, p. 69).

The citation above shows that Lima anak Mataram made Jember festival and Rio de Janeiro Carnaval as the inspiration in conducting big event in Mataram. The identity of Mataram maintained is the identity of Mataram which is multicultural, which is opened with the changes. The name of Mataram City Festival is proposed by Lima Anak Mataram. 


\begin{abstract}
Before delivering the name of the event, Haji Lalu Makmur Said took the time to look at his notes while asking the mayor's permission to continue the report. There are some basic things that are considered. Lima Kenari Mentaram was asked to determine the name of this event, such as accommodating the brilliant ideas of all website readers around the world, holding on to the development jargon of Mataram for all, making Mataram as the center of civilization and culture, including ideas that state anything in the world, all stems from Mataram, and for all the people of Mataram, make Mataram as a development constitution. In fact, there are some considerations that are unique and seem funny, when the brain is unable to determine the best, then it must return to the simplest of these brilliant ideas. It is on this basis that Lima kenari Mentaram set the name of the "Semua Mentaram Festival" event. Then they abbreviate it as "Semen Fes" (Faris, 2013, pp. 205-206).
\end{abstract}

The government of Mataram City entrusts the event to Lima anak Mataram. How the event is designed and the steps including the places selected for the opening and closing event is decided by Lima anak Mataram. In giving the name to the event, Lima anak Mataram is inspired from the jargon of Matram City, namely the development of Mataram for all.

\title{
Position of Java in the culture of Sasak Lombok
}

Satrya (2018) shows the hegemonic position of Java in the production of Sasak Lombok's culture. Java is related to the nobility of Sasak. The production of Sasak's culture mainly in the ancient manuscripts is conducted by the nobleman. Satrya (2018) explains how that hegemony of Java occurs until reaching the history of Sasak people's origin. Meij (2011) mentions that the ancient manuscripts of Lombok use the language of Eastern Coast Java. Marrison (1997) sees the relationship between Java and Lombok especially in the process of Islamization. Jamaludin $(2011,2019)$ emphasizes the position of Java in the process of Islamization in Lombok. The culture of Lombok is related to Islam which correlates with the culture of Java. The ancient manuscripts which contain morality of Sasak people are elaborated from the Java's ancient manuscripts. Therefore, Lombok literatures are written in Javanese and are assumed as the part of Javanese literature (G E Marrison, 1997; Geoffrey E. Marrison, 1999). This condition showed the importance of the position of Java in the production of Sasak's culture. Java as the centre and Sasak as the marginal. The centrality of Java survived until new orde era. It can be seen from the political perspective of the government. (MacDougall, 2005).

\section{CONCLUSION}

The novel Kenari Mentaram constructs Mataram as a tourism destination. This novel utilizes art as a means to attract tourists. This novel highlights the tourism locations in Mataram, for example Loang Balok Park, Sangkareang Park, and Udayana Park. The novel discourses park as an enjoyable place and art space. Udayana Park is made as the centre of art event. The art event proposed by Lima anak Mataram influences the policy of the major of Mataram City. Art and tourism are essential thing for Mataram City. Art and tourism as the means to internationalize Mataram City. The internationalization through art and tourism is produced by the discourse of Mataram as a multicultural city. That discourse is a part of contemporary discourse of Indonesia including 
Edulite Journal of English Education, Literature, and Culture Vol. 6, No. 1, February 2021, pp. 179-188

E-ISSN: 2528-4479, P-ISSN: 2477-5304 http://jurnal.unissula.ac.id/index.php/edulite DOI: http://dx.doi.org/10.30659/e.6.1.179-188

Java. By taking Java as the model, that novel restores Sasak as the part of Java in developing art and tourism in Mataram City. The discourse of that novel restores Sasak Mataram to Java Mataram. That restoration is conducted in the context of economization of Lombok.

\section{REFERENCE}

Budiwanti, E. (2014). Balinese Minority versus Sasak Majority: Managing ethnoreligious diversity and disputes in Western Lombok. Heritage of Nusantara: International Journal of Religious Literature and Heritage, 3(2), 233-250. https://doi.org/10.31291/hn.v3i2.11.

Faris, S. (2013). Kenari Mentaram. Bappeda Kota Mataram \& IAIN Mataram.

Faruk. (1995). Perlawanan tak kunjung usai. Pustaka Pelajar.

Faruk. (2018). Nasionalisme puitis: sastra, politik, dan kajian budaya. Pustaka Pelajar.

Jamaludin. (2011). Sejarah sosial Islam di Lombok tahun 1740-1935 (Studi Kasus terhadap Tuan Guru). Kementerian Agama.

Jamaludin. (2019). Sejarah Islam Lombok: Abad ke-16 hingga abad Ke-20. LEPPIM IAIN Mataram.

Kurnia, M. D. (2015). Warna lokal Melayu pada Novel Ayah karya Andrea Hirata. Deiksis, 141-163. http://dx.doi.org/10.33603/deiksis.v4i1.414.

MacDougall, J. M. (2005). Buddhist Buda or Buda Buddhists?: Coversion, religious modernism and conflict in the minority Buda Sasak Communties of New Order and Post-SUgarto Lombok. Princeton University. http://buddhism.lib.ntu.edu.tw/DLMBS/jp/search/search_detail.jsp?seq=1290 94.

Marrison, G. E. (1997). The literature of Lombok: Sasak, Balinese, and Javanese. Indonesia and the Malay World, 73(October), 221-234. https://doi.org/10.1080/13639819708729901.

Marrison, G. E. (1999). Sasak dan Javanesse Literture of Lombok. KITLV.

Satrya HD, D. (2018). Feudalism versus Capitalism: The Changing Representation of Lombok in Nadira Khalid's Novel Ketika Cinta Tak Mau Pergi. 3L: Language, Linguistics, Literature, 24(4), 115-127. https://doi.org/10.17576/3L-2018-2404$\underline{09}$.

Satrya HD, D., Faruk, \& Pujiharto. (2019). Romanticism and New Awareness in Indonesian Literature: Lombok's Representation in Novel Opto Ergo Sum. In English Language and Literature International Conference (pp. 341-349). https://doi.org/10.4108/eai.27-4-2019.2285292.

Sesnic, J. (2007). From Shadow to Presence: Representation of Ethnicity in Contemporary American Literature. Rodopi.

Subardini, N. N. (2011). Stratifikasi Masyarakat Bali dalam "Tarian Bumi" dan "Kenang" karya Oka Rusmini, 214-227.

Suroso. (2011). Kepriyayian Tokoh dalam Novel Warna LOkal Jawa dan Sumbangannya dalam Pengembangan Karakter Bangsa. Litera, 1O(2), 183-191. https://doi.org/10.21831/1tr.v10i2.1162.

Trisnawati, I. A., Ardika, I. G. L. O., \& Kariasa, I. N. (2016). "Strands of Gumi Sasak Pearls" Harmony-based Tourism Products in Mataram City, West Nusa 
Satrya HD, D., \& Nursaly, B.R. (2021). Back to Java: The discourse of Lombok art in Salman Faris's Kenari Mentaram. EduLite: Journal of English Education, Literature, and Culture, 6 (1), 179-188. http://dx.doi.org/10.30659/e.6.1.179-188

Tenggara. Mudra Jurnal Seni Budaya, 31(3). https://doi.org/10.31091/mudra.v31i3.44.

Van der Meij, D. (2011). Sastra Sasak: Selayang pandang, 1 Nomor 1, 17-45.

Wildan, W. (2013). Kearifan lokal dalam novel Seulusoh karya D. Kemalawat. Bahasa dan Seni: Jurnal Bahasa, Sastra, Seni, dan Pengajarannya, 41(1). http://journal2.um.ac.id/index.php/jbs/article/view/94.

Conflict of Interest Statement: The authors declare that the research was conducted in the absence of any commercial or financial relationships that could be construed as a potential conflict of interest.

Copyright (c) 2021 Satrya and Nursaly. This is an open-access article distributed under the terms of the Creative Commons Attribution License (CC BY). The use, distribution or reproduction in other forums is permitted, provided the original author(s) and the copyright owner(s) are credited and that the original publication in this journal is cited, in accordance with accepted academic practice. No use, distribution or reproduction is permitted which does not comply with these terms. 